\title{
EMBEDDING VIRTUAL REALITY INTO COMPETENCE RECOGNITION
}

\author{
Merja Drake \\ Haaga-Helia University of Applied Sciences \\ Ratapihantie 13, FIN 00520 Helsinki, Finland
}

\begin{abstract}
Nearly every third present occupation will disappear by the year 2030. While today's workplaces play a significant role in competence recognition, a degree is only one part of developing skills and competences (Ministry of Education and Culture 2019). Therefore, we need to shape the politics of lifelong learning's core, which is expertise instead of degrees. Virtual reality (VR) can offer both educators and businesses an exciting possibility for optimising competences and learning processes (Melo, Bentley, McAllister \& Cortez 2019). The use of VR has been studied to some extent, but mainly in school and university contexts. Its use has been limited in terms of employment training and competence recognition (Huang, Rauch \& Liaw 2010); therefore, this area requires further study.

The aim of this research is to develop and test the use of VR in identifying needed competences in working life and in supporting employment training so that language skills are a minimum constraint. The main target group is immigrants in Finland. This ongoing research will be conducted in a Living Lab.
\end{abstract}

\section{KEYWORDS}

Virtual Reality, Competence Recognition, Life Long Learning

\section{INTRODUCTION}

Futurist speaker Thomas Frey (2019) claims that 'Businesses today care far less about someone's degree or underlying coursework and far more about whether they've been able to pass the necessary certification tests'. He also thinks that we will soon have micro colleges to meet this need. Our working, teaching and living environments are indeed changing at an accelerated pace. Nearly every third present occupation will disappear by the year 2030. While today's workplaces play a significant role in competence recognition, a degree is only one part of developing skills and competences (Ministry of Culture and Education 2019). Therefore, we need to shape the politics of lifelong learning's core, which is expertise instead of degrees.

Immigrants are predicted to play a key role in maintaining an adequate level of Finland's working-age population. Four of five foreigners who are living in Finland are of working age; however, the employment rate of working-age immigrants is considerably lower than that of the general population (Eronen et al. 2014). One of the biggest obstacles to employing immigrants is a lack of language skills. The bigger an economic advantage that is provided, the faster more immigrants will be employed. If young people stay outside education and outside working life, it has the negative effects, which will last for $\sim 5-7$ years. (Åslund \& Rooth 2007).

Per the Organisation for Economic Co-operation and Development's (OECD) 2018 report, earlier attempts to employ immigrants have not been successful, and new bold initiatives to solve the problem need to be developed. The objective of the current project is to develop and test the use of virtual reality (VR) in identifying needed competences in working life and in supporting employment training, especially for immigrants, so that language skills are a minimum constraint. The goal is also to increase the awareness of companies, including recruitment agencies, in using VR for recruiting, work training and task orientation. 


\section{LITERATURE REVIEW}

Per the VR Society (2019), "Virtual reality is the term used to describe a three-dimensional, computer-generated environment, which can be explored and interacted with by a person. That person either becomes part of this virtual world or is immersed within this environment and, whilst there, is able to manipulate objects or perform a series of actions'. VR is an immersive experience meaning human is deeply concentrated on his tasks and not realising being in a virtual world. Immersion can help learning by reducing external disturbing factors. (Witmer, Jerome \& Singer 2005.) VR is said to elaborate problem-solving capability and improve learning engagement (Zhen, Xie \& Liu 2018)

Kulik, Kunert, Beck and Frölich (2017) suggest that virtual learning should be highly interactive because people learn by doing. VR learning can include collaborative interaction with others if it can focus on the environment, but learning also necessitates individual autonomy. Huang et al. (2013) claim that VR learning enhances interpersonal communication as well as a service mindset.

VR could be particularly useful for training immigrants because instructions need not necessarily be linguistic. Instead, training modules can be produced so that the correct modes of action are firstly demonstrated before being practiced. In addition, exercises can be repeated safely, and knowledge can also be verified on a virtual world screen. The biggest obstacles to using VR are the cost and human resources (Kavanagh et al. 2017). However, decreasing software and equipment costs are making more experiments possible.

\section{RESEARCH QUESTIONS AND METHOD}

The objective here is to develop a VR-based fast-track model for competence recognition together with immigrant organisations and entrepreneurs to open new employment avenues. The research method is based on the Living Lab approach, which is a user-centred ecosystem that aims to produce innovations, new products and new services in collaboration with users, citizens, companies and researchers (Chesbrough 2003). The idea of the Living Lab is to solve everyday problems and boost the economy by practice-based innovation, rapid development and testing of users (Pallot et al. 2011). We will build the ecosystem with companies, immigrant organisations, local employment authorities and educational institutions, while we alone will develop the VR recognition system, test it and use it. Once it provides competence recognition, companies will be able to employ the most suitable candidates. We will conduct three different employment experiments, with each lasting six months. In total, over 100 immigrants aged 24 to 64 and 50 companies will participate in the ecosystem.

Our research questions will include the following: 1) What is the best way to develop a competence recognition model using VR to employ immigrants in a particular field or position? 2) What kind of competence recognition model best serves participating companies in finding the proper expertise? 3) How satisfied are the immigrants and the company representatives with the competence recognition model?

The research data will be drawn from brainstorming, co-creation workshops and developing and testing workshops of the competence recognition system. We will collect additional data both during and after the employment experiment by interviewing both immigrants and the representatives of the companies. The data will be analysed by content analysis. The project is financed by the European Social Fund.

\section{REFERENCES}

Åslund, O. \& Rooth, D-O. 2007. Do When and Where Matter? Initial Labour Market Conditions and Immigrant Earnings (0000). The Economic Journal, vol. 117, no. 518, pp. 422-448, March. <https://ssrn.com/abstract=978574 or http://dx.doi.org/10.1111/j.1468-0297.2007.02024.x>.

Chesbrough, H. W. 2003. Open innovation: The new imperative for creating and profiting from technology. Boston: Harvard Business School Press.

Eronen, A., Härmälä, V., Jauhiainen, S., Karikallio, H., Karhinen, R., Kosunen, A., Laamanen, J-P. \& Lahtinen, M. 2014. Maahanmuuttajien työllistyminen. Taustatekijät, työnhaku ja työvoimapalvelut. (Labour Market of Immigrants in Finland) Työ- ja elinkeinoministeriön julkaisuja. Työ ja yrittäjyys 6/2014. 
Frey, T. 2019. Are certifications more valuable than college degrees? <https://futuristspeaker.com/future-ofeducation/are-certifications-more-valuable-than-college-degrees/>.

Huang, H-M., Rauch, U. \& Liaw, S-S. 2010. Investigating Learners' Attitudes toward Virtual Reality Learning Environments: Based on a Constructivist Approach. Computers \& Education, vol. 55, no. 3, pp. 1171-1182, Nov.

Kavanagh, S., Luxton-Reilly, A., Wunche, B. \& Plimmer, B. 2017. A systematic review of Virtual Reality in education. Themes in Science \& Technology Education, vol. 10, no. 2, pp. 85-119.

Kulik, A., Kunert, A., Beck, S. \& Frölich, B. 2017. Collaborative virtual reality for joint learning experiences. Proceedings CSCL, pp. 721-722.

Melo, M., Bentley, E., McAllister, K. \& Cortez, J. 2019. Pedagogy of Productive Failure: Navigating the Challenges of Integrating VR into the Classroom. Journal of Virtual Worlds Research. vol. 12, no. 1, pp. 1-21.

Ministry of Education and Culture 2019. Jatkuvan oppimisen kehittäminen (Developing lifelong learning). http://urn.fi/URN:ISBN:978-952-263-641-6.

OECD 2018. Working Together: Skills and Labour Market Integration of Immigrants and their Children in Finland., Paris: OECD Publishing. <https://doi.org/10.1787/9789264305250-en>.

Pallot, M., Trousse, B., Senach, B. \& Scapin, D. 2011. Living Lab Research Landscape: From User-Centered Design and User Experience towards User Cocreation. First European Summer School 'Living Labs', Inria (ICT Usage Lab), Userlab, EsoceNet, Universcience, Aug 2010, Paris, France. $<$ https://hal.inria.fr/inria-00612632>.

Virtual Reality Society 2019. What is virtual reality?. https://www.vrs.org.uk/virtual-reality/what-is-virtual-reality.html retrieved 10.10.2019.

Witmer, B., Jerome, C. \& Singer, M. 2005. The Factor Structure of the Presence Questionnaire. Presence: Volume 14. Number 3, pp. 298-312.

Zheng, L., Xie, T. \& Liu, G. 2018 Affordance of Virtual Reality for Collaborative Learning. 2018 International Joint Conference on Information, Media Na Engineering (ICIME). 